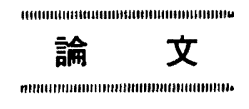

UDC $669.15-194: 539.211: 539.55$

\title{
低炭素鋼の衝撃破面と鞄性に関する二, 三の検討"
}

\author{
寺 崎 富久長**.大 谷 泰 大*** $^{* *}$ \\ Study on Relationship between Impact Fracture Surface \\ and Toughness of Low-carbon Steels
}

Fukunaga Terasaki and Hiroo Ohtani

\begin{abstract}
Synopsis :
The brittle fracture surfaces of steels are closely related to the microstructures, and it has been shown that there is a good correlation between the unit crack path $\left(l_{\mathrm{c}}\right)$ and the impact transition temperature $(v \operatorname{Tr} S)^{4-6)}$.

In this study, it is confirmed that the unit crack path in the ferrite-pearlite structure can be used as the factor controlling the toughness of steel; there is a linear relation between $v \operatorname{Tr} S$ and $\log l_{\mathrm{c}}{ }^{-1 / 2}$, as previously obtained in the quenched structures. The relationship among the austenite grain size, the ferrite grain $\operatorname{size}(l \alpha)$, and the unit crack path in the ferrite-pearlite structures is determined. The relation $l_{\mathrm{c}} \simeq 2 l_{\alpha}$ is obtained, as expected in the previous paper.4)

The fracture appearance in the brittle-ductile transition range of the ferrite-pearlite and the quenched structures are also invesitgated. In increase of the temperature from the brittle range in Charpy impact test, the ductile networks enclosing the brittle fracture facet are observed. The brittle fracture facet itself becomes ductile with further increase of temperature. However, the unit crack path is found to be unchanged, accordingly, this value is considered as a characteristic of the structure. The areal amounts of the ductile fracture measured by the scanning electron microscope are closely related to the Carpy impact values.

(Received June 4, 1971)
\end{abstract}

\section{1. 緒言}

フェライトトパーライト縕織について, 強度や鞋性が 結晶粒度に依存することはよく知られており理諭的な検 討も行なわれている1) 3). しかしながら，調質鋼などの 複雑な組織の場合には，これらの結晶粒度に相当する ものが必ずしも明確ではなく，低温脆性破面も擬䢃開 (quasi-cleavage) 破面と呼ばれている.

前報4 6)では, 組織と脆性破面の関連について走査電 子顕微鏡を用い, 各種变態組織について破面と組織の直 接対応を試みた。 その結果, 破面は組織と密接な関係に あり, 変態組織がある領域でほぼ同一の結晶方位をもつ 場合には, 擬䢃開破壊はこの領域を単位として $\{100\}$ 面 で生ずることが得られた。すなわち，擬䢃開破面は微細 な破面単位からなり，この破面単位は微細急裂の生成伝 播が生じている領域に相当し，この中では破壊の生じて いる結晶面の方位が，ほぼ同一の $\{100\}$ 面をなくしてい る. 靶性との関連については, シャルピー衝整破面遷移 温度と破面単位がよい相関にあることが得られている5).

しかしながら，これらの破面単位は脆性領域での破面
単位であり，奚移温度と対応させるためには，遥移領域 での波面を調査する必要がある。また破面観察から材料 の歎性や破壊の外的条件を論議するためには，遷移領域 での破面の変化を調べる必要がある，この意味で本報で は, 比較的単純なフェライト十パーライト組織を中心に 調査し，併せてマルテンサイトやマルテンサイト+ベイ ナイト混合組織などの焼入組識について, 遷移領域の破 面と組嬂との関連について調查した結果を報告する.

\section{2. 供試材と実験方法}

供試材の化学成分を Table 1 に示す.

鋼 $\mathrm{F}$ は,フェライト十パーライト鋼として実験に供し たものである. 鋼 7, 8 は，前報と同様の試料であり5), オーステナイト化温度より連続冷却時の冷却速度を变え ることにより，マルテンサイト+ベイナイト混合組織お よびマルテンティト組織としたものである.

* 昭和 46 年 4 月本会講演大会にて発表 昭和 46 年 8 月 4 日受付

** 住友金属工業(株)中块技術研究所理博

****住友金属工業(株) 中央技術研究所 
Table 1. 供試鋼の化学成分

\begin{tabular}{|c|c|c|c|c|c|c|c|c|c|c|c|c|c|}
\hline & C & $\mathrm{Si}$ & $\mathrm{Mn}$ & $P$ & $\mathrm{~S}$ & $\mathrm{Cu}$ & $\mathrm{Ni}$ & $\mathrm{Cr}$ & Mo & V & B & $\mathrm{Ti}$ & $\begin{array}{c}\text { Sol. } \\
\mathrm{Al}\end{array}$ \\
\hline & & & & 0.016 & 0.019 & & - & & & & - & - & 0.025 \\
\hline 7 & & & & & & & & & & & & - & 0.038 \\
\hline 8 & 0.1 & 0.26 & 0.89 & 00 & 00 & 0.27 & 1 . & 0.54 & . 50 & 0.003 & 0.004 & 0.03 & 0.044 \\
\hline
\end{tabular}

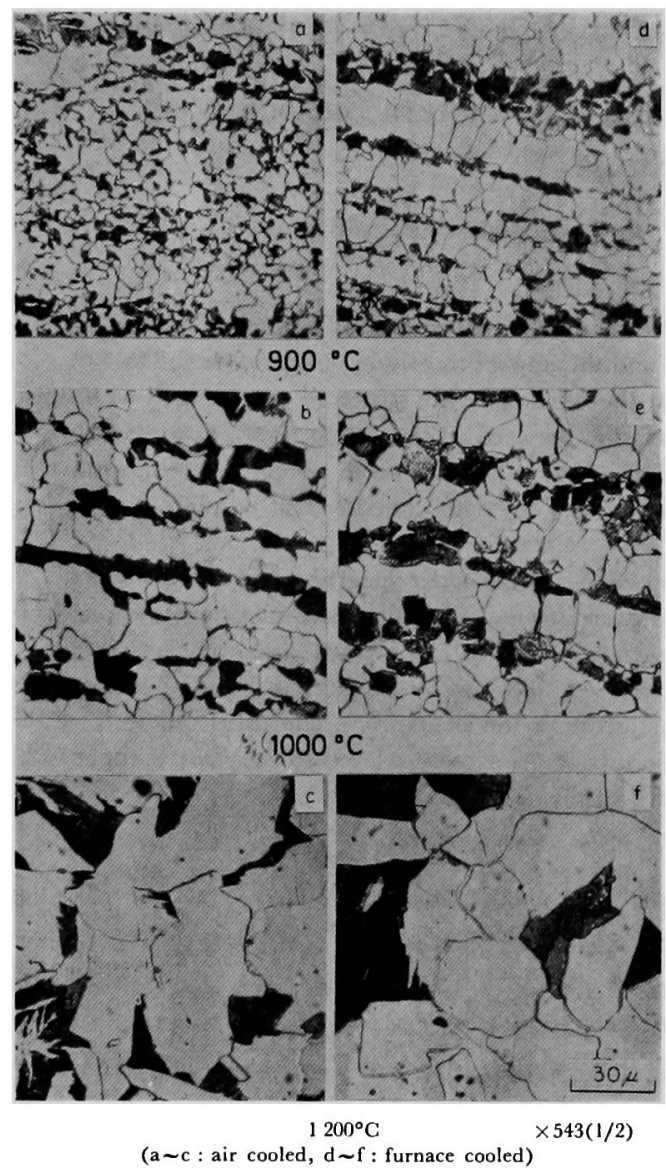

Photo. 1. Optical microstructures of materials used (steel F).

試料 Fについては, $12 \mathrm{t} \times 200 \mathrm{w} \times 250 \mathrm{l}(\mathrm{t}, \mathrm{w}, 1$ はそれ ぞれ厚み，幅，長さを示す）の素材を $900 〜 1200^{\circ} \mathrm{C}$ の 温度で $30 \mathrm{~min}$ 保持し，種々のオーステナイト粒にした 後, 各温度から空冷, 炉冷の 2 種類の冷却速度にて冷却 し，各種のフェライト粒を有するフェライト十パーライ 卜組織を得た. 鋼 7,8 は, $7 \mathrm{t} \times 12 \mathrm{w} \times 601$ の素材を $1200^{\circ} \mathrm{C} \times 20 \mathrm{~min}$ 加熱保持後, それぞれ油冷 (800〜 500 ${ }^{\circ} \mathrm{C}$ の平均冷却速度 : $\left.23^{\circ} \mathrm{C} / \mathrm{sec}\right)$ および水冷 $\left(200^{\circ} \mathrm{C} / \mathrm{sec}\right)$ の冷却速度で冷却することにより，マルテンサイト十ベ イナイト混合組織およびマルテンサイト組織とした. 熱
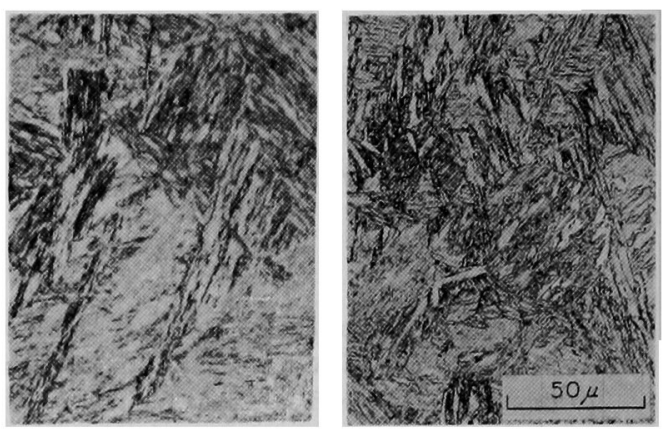

H sat treatment

a) $1200^{\circ} \mathrm{C} \times 20 \mathrm{~min} O Q$

b) $1200^{\circ} \mathrm{C} \times 20 \mathrm{~min} W Q$

Photo. 2. Optical microstructures of materials used.

処理後の光学顕微鏡写真を Photo. 1 および Photo. 2 に 示す. シャルピー沺撃試験は, 鋼 F については通常の $2 \mathrm{mmV}$ 切欠を有する $10 \mathrm{t} \times 10 \mathrm{w} \times 55 \mathrm{l}$ の試験片で行な い, 鋼 7, 8 については, $2 \mathrm{mmV}$ 切火を有する $5 \mathrm{t} \times$ $10 \mathrm{w} \times 551$ のサブサイズ試験片で行なつた.

破面の観察は，走査電子顕微鏡によつて行なつた．遷 移領域では一般に破面の凹凸が著しく, 脆性破面中に混 在する延性破面帯は, 多くは破面の不連続部に階段状を なして存在する．これらをより明確に観察するため本実 験では, 破面を破面に垂直方向より $30^{\circ}$ 破壊の進行方向 側に傾けて観察を行なつた.

延性破面の面積率の測定は，破面全体を 10 倍に拡大 し, これよりマクロ的破面率を求めた. 々ク口破面率は, マク口的延性破壊部には脆性破面部は存在しなかつたの で, マクロ的にみた脆性破面部中の延性破面率を求めマ ク口的破面率を補正することによつて得た. すなわち走 査電子顕微鏡を用い，他の観察と同様 $30^{\circ}$ 傾けた破面を 100 倍にて撮影した. 撮影場所は破面中心部を香裂進行 方向に沿つて幅 $1 \mathrm{~mm}$, 長さは破面全長にわたつて 撮 り，この場所の破面率で胞性破面全体を近似した。

\section{3. 実験結果と検討}

\section{1 破面単位と逗移温度}

前報45) では, 破面単位として 微視的な亀裂の発生, 伝播，停止領域の大きさを破面単位と定義し，この大き さと破面燢移温度 $(v \operatorname{Tr} S)$ とはよく対応することを示し 


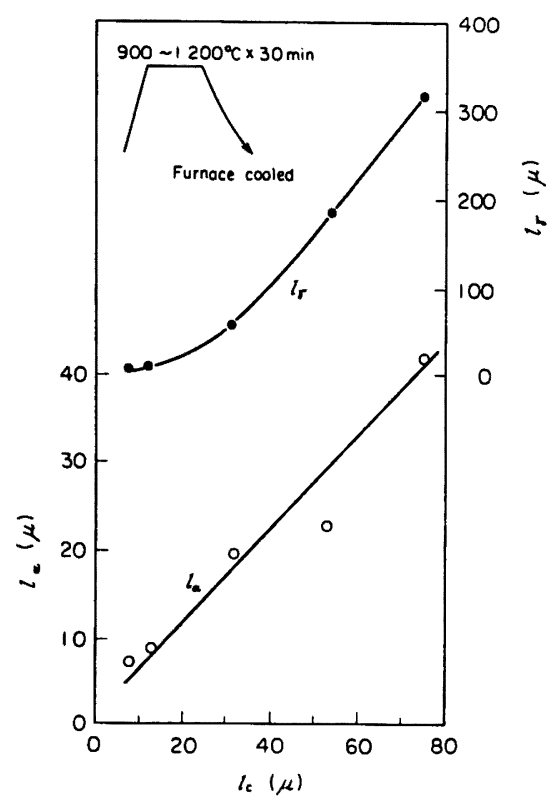

Fig. 1. Relation of austenite grain size $\left(l_{\gamma}\right)$, ferrite grain size $\left(l_{\alpha}\right)$ and unit crack path $\left(l_{\mathrm{c}}\right)$ for ferrite-pearlite structure. (steel F)

た. Fig. 1 は, オーステナイト結晶粒度, フェライト結 晶粒度と破面単位との関係を示したものである. 測定は いずれも線分析で行なつたもので，オーステナイト粒 $\left(l_{r}\right)$, フェライト粒 $\left(l_{\alpha}\right)$, 破面単位 $\left(l_{\mathrm{c}}\right)$ はいずれも平均 截片長さである.

この結果から明らかなごとく， $l_{\alpha}$ と $l_{\mathrm{c}}$ とは直線関係 を示し, $l_{\mathrm{c}} \approx 2 l_{\alpha}$ になつており, 平均して 4 個程度のフ ェライト結晶粒が一つの破面単位を形成していることを 示している. 前報)では，同一のオーステナイト粒から ランダムに K-S の関係でフェライト粒が生成した場合 には, $2 \sim 3$ 個のフェライト粒が 1 つの破面単位を形成 することを示したただしこの場合は，隣接粒との方位 差が $10^{\circ}$ 以内である場合に限られており, 前報の実験結 果4でもその一例を示したごとく，一部には $20^{\circ}$ 程度で も破面単位としての有効な境界を形成しない場合があ る. すなわち, 本実験結果は 1 つには, $20^{\circ}$ 程度の差で あつても外部応力条件と破面の結晶方位との関係で，も つとも容易な破壊の方位関係をもつものは, 有効な亀裂 伝播阻止効果を示さないと考えられる. さらに K-S 関 係が隣接粒に対して，まつたくランダムであるかどうか についても現在のところ不明であり，あるいはこれらが 寄与しているのかもしれない. $l_{\gamma}$ と $l_{\mathrm{c}}$ との間には直線関係はなく， $l_{\gamma}$ が大きくなつ ても $l_{\alpha}, l_{\mathrm{c}}$ ともそれほど大きくならない， $r / \alpha$ 変態時 の粒の生成は，オーステナイト粒界から始まることにつ いてはいくつかの実験結果もあるが7)，この観点からは， フェライト粒生成の核発生位置が多い細 $\gamma$ 粒材の方が, より分割の度合が大になるものと考えられる。しかしな がら，分割の度合は核発生のみでなく粒成長とのかね合 いによるものと考えられ；空冷材と炉冷材では，才ース テナイト粒は同じでもフェライト粒は炉冷材の方が大き くなつている．このような分割の度合は $A r_{3} \sim A r_{1}$ の間 の冷却パターンに支配されるものと考えられる.

Fig. 2 は, 破面単位 $\left(l_{\mathrm{c}}\right)$ と $v \operatorname{Tr} S$ の関係を示してい る. $v \operatorname{Tr} S$ と $\log l_{\mathrm{c}^{-1 / 2}}$ とはよい直線関係を示しており， A.C., F.C. の差異はない. すなわち, 泠却速度の影響 は本実験の場合，破面単位を通じて遷移温度に寄与する といえる. 本実験は，種々の熱処理条件を変えて結晶粒 度を変えた場合に，破面単位，フェライト粒と $v \operatorname{Tr} S$ と の間の関係が異なることを期待したのであるが，Fig. 1 に示すごとく $l_{\alpha}$ と $l_{\mathrm{c}}$ はよい対応を示し，オーステナ イト温度, 炉冷, 㚙冷による冷却速度程度の処理範囲内 では $v \operatorname{Tr} S$ と $l_{\mathrm{c}}$ の関係同様, $v T r S$ と $l_{\alpha}$ の関係もまた よい対応を示すことは明らかである，したがつて，本実 験範囲では $l_{\tau}, l_{\alpha}, l_{\mathrm{c}}$ が細かくなれば $v T r S$ は低下す る.

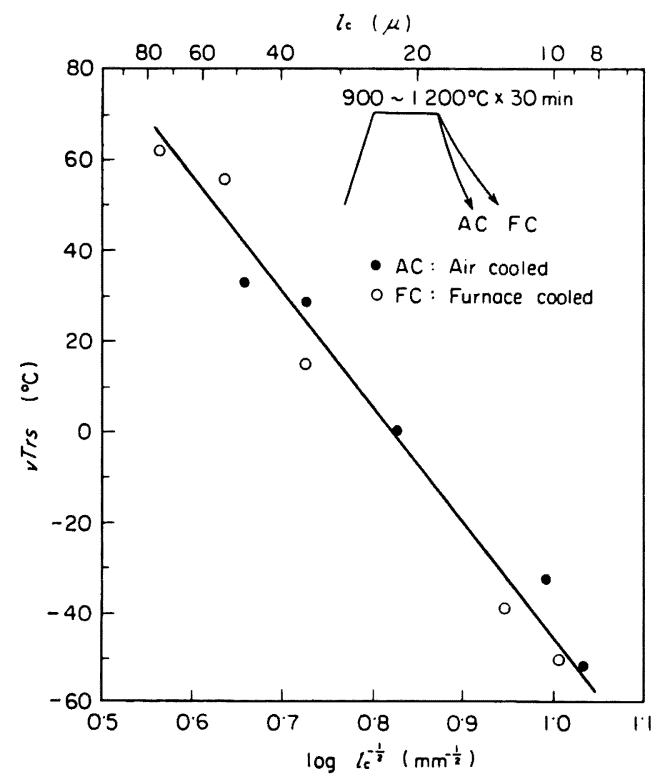

Fig. 2. Relation between impact transition temperature and unit crack path for ferritepearlite structure. (steel F) 


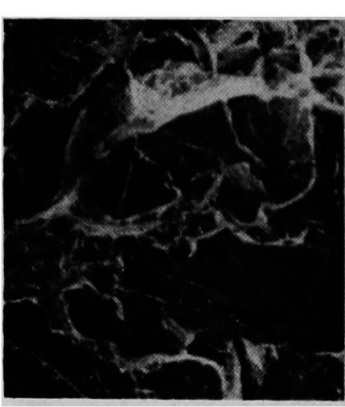

$60^{\circ} \mathrm{C}$

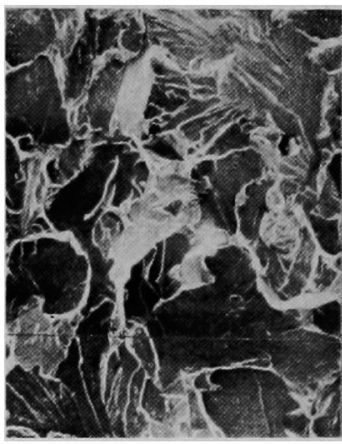

$-196^{\circ} \mathrm{C}$

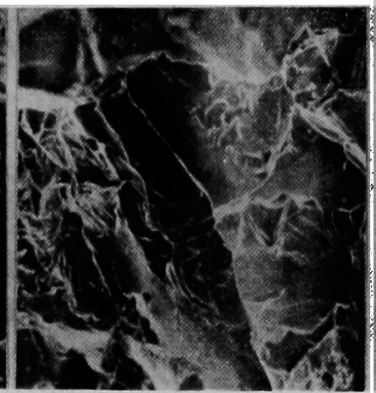

$80^{\circ} \mathrm{C}$

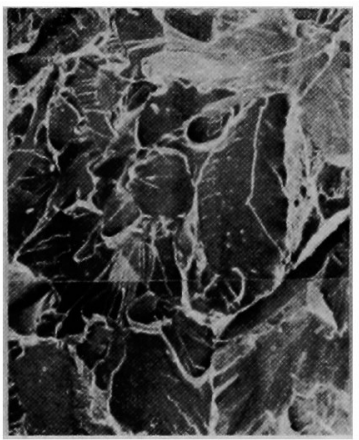

$0^{\circ} \mathrm{C}$

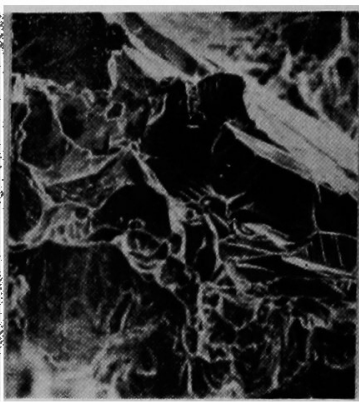

$120^{\circ} \mathrm{C}$

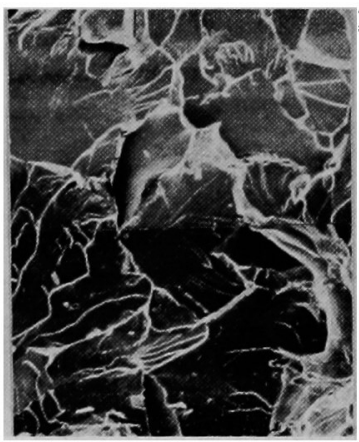

$20^{\circ} \mathrm{C}$

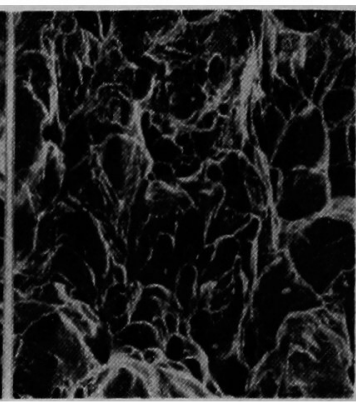

$140^{\circ} \mathrm{G}$

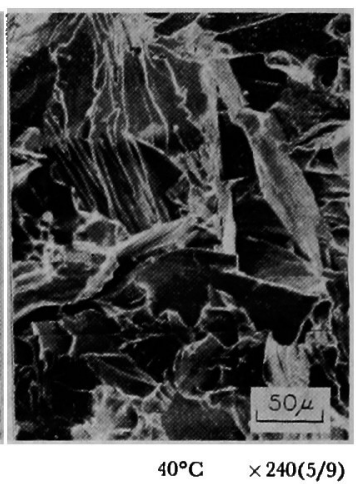

Photo. 3. Variation of fracture appearance with temperature for ferrite-pearlite structure. (steel F : furnace cooled from $1200^{\circ} \mathrm{C}$ )

\section{$3 \cdot 2$ 破壊温度と破面の様相}

以上の結果は，すべて脆性領域で測定した破面単位に ついての結果である.しかしながら, 試験温度の上昇に ともない亀裂伝播抵抗が増加するので破面単位が変化す ることも考光られたので，これらの点について $v T r S の$ 得られる遷移領域で破面単位を測定した.

Photo. 3 は, $1200^{\circ} \mathrm{C} \times 30 \mathrm{~min}$ F. C. 処理材のシャル ピー破面の温度变化を示している. Photo. 3 はシャルピ 一破面のほぼ中心部で䢃開破面の残存部を選択的に撮影 したものである. 試験温度が上昇するにつれて, 䢃開破 面部は減少するが, Photo. 3 から明らかなごとく, 破面 単位はほとんど温度に依らず一定である。 また脆性一延 性遷移における䢃開部のリバー・ パターンなど破面単位 内部の変化はそれほど明嘹ではない，温度が上昇すると まず破面単位の周囲に延性破壞帯が生じ，これが網目状 に存在するようになる.ついで特定の破面単位全体が延 性破面を呈するようになり, 最終的な延性破面へと移行 している.

Fig. 3 は，衝撃破面の温度変化を示したものである. 上段はマク口的にみた延性破面率を示し，下段にはうク 口的にみ大延性破面率を示している. 之ク口的延性破面 率はマク口的に久て脆性破面であつても, Photo. 3 に示
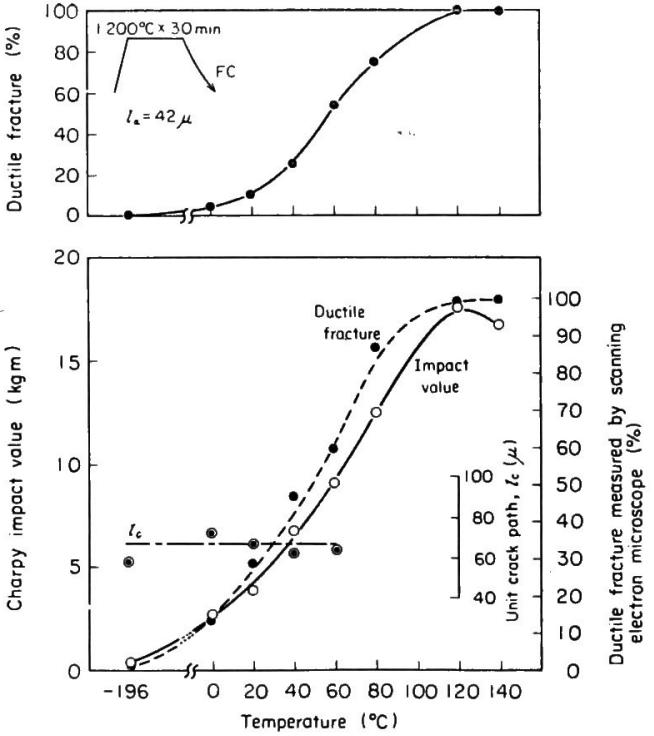

Fig. 3. Charpy impact transition curve, unit crack path and ductile fracture area $(\%)$ measured by scanning electron microscope for ferritepearlite structure. (steel F) 
すごとく，部分的に延性破面が混在しており，これらを すべて含めた延性破面率である. Fig. 3 は，吸收エネル ギーと並べて図示してあるが，これからわかるごとく， 両者はかなりよい一致を示している，すなわち，憵開破 面はほとんど吸収エネルギーに寄与せず，有効表面エネ ルギーは，延性破面が大部分を占めることを示してい る.さらにこの延性破面の有効表面エネルギーは実験範 囲では顕著な温度依存性はなく, 温度の上昇は, 見かけ 上延性破面率の増加をもたらすと解される。 Fig. 3 に は，破面単位の大きさの温度变化も示されているが，明 らかに温度によつて変化していない，この点からみて破 面単位は組織固有の大きさであつて，前報4) 6)までの脆 性領域での測定のみで十分であると考えられる.

\section{3 焼入材における破壊温度の影響}

以上はフェライト+パーライト鋼についての結果であ るが，前報ら）で用いた調質鋼（鋼 7，8）の場合をそれぞ
れ Photo. 4, Photo. 5 に示す. Photo. 4 は, マルテン サイト組織の場合である. 破面の様相は, フェライト十 パーライトの場合とほぼ同様であり, 破面単位の周囲に 延性破壞寡が生じ，さらに温度の上昇とともに一部の破 面単位が延性破壊域に变化している。

Photo. 5 は，前報で示された镸移温度が泠却速度に対 して最も低くなる最適な冷却速度域で熱処理された材料 であり，組織的にはベイナイト+マルテンサイト混合組 織である5)。この場合は，ベイナイトによるもとの才ー ステナイト粒の分割効果のため，小さい破面単位が得ら れるものと考えられたが5 破面単位もフェライト+パー ライト粒やマルテンサイトのごとき等㠹形をもたず，長 方形に近くなる.破面単位の構成もやや不明りようにな るが，延性-脆性遷移にともなう延性破壊の生成につい ては，マルテンサイトやフェライト十パーライトと同様 な傾向を示している.

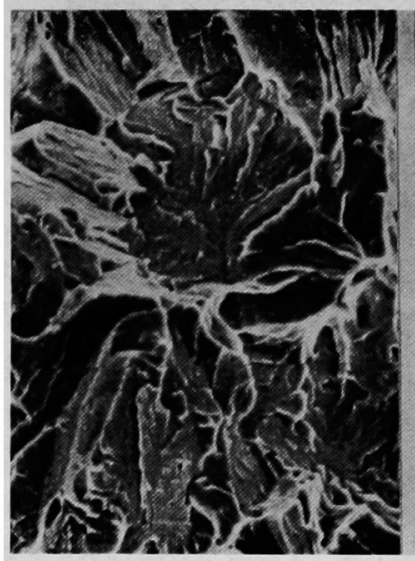

$0^{\circ} \mathrm{C}$

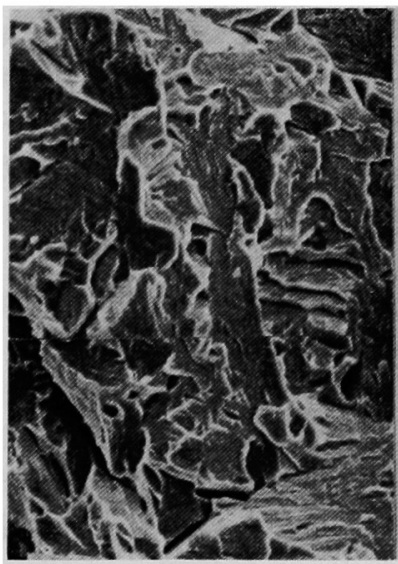

$-60^{\circ} \mathrm{C}$

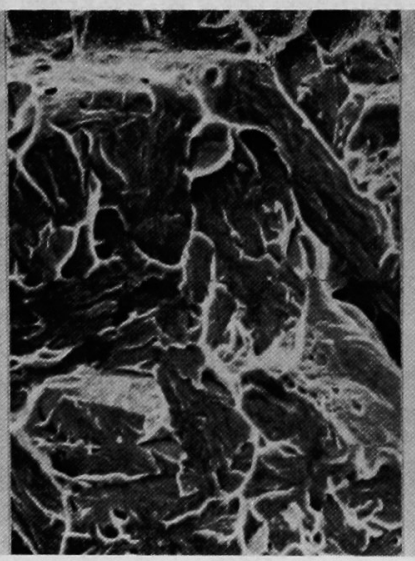

$30^{\circ} \mathrm{C}$

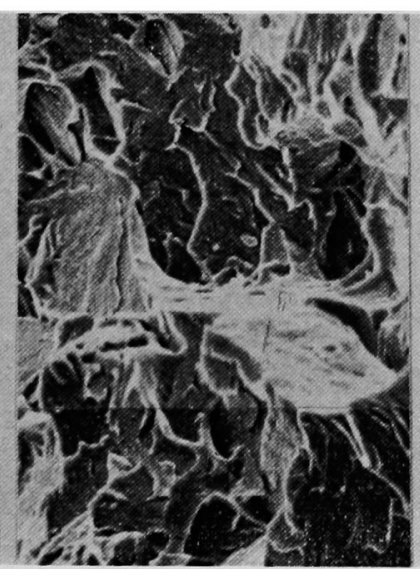

$-40^{\circ} \mathrm{C}$

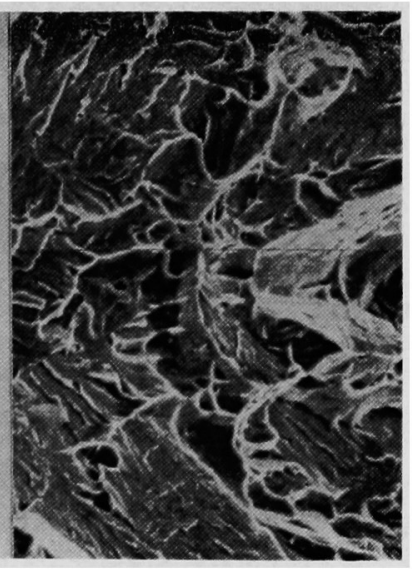

$60^{\circ} \mathrm{G}$

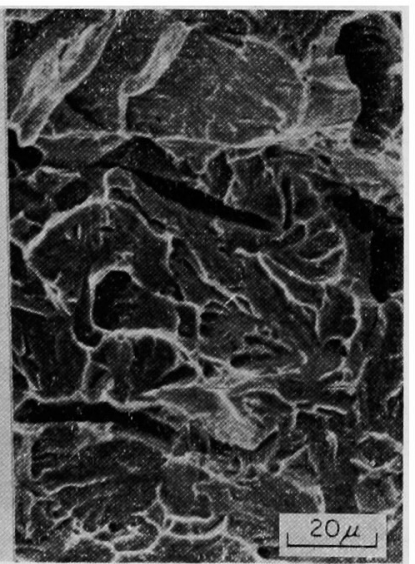

$-20^{\circ} \mathrm{C}$

$\times 800(3 / 5)$

Photo. 4. Variation fo fracture appearance with temperature for martensitic structure (steel 8). 
Fig. 4，Fig. 5 は, 衝撃破面の温度依存性を示したも のである. 焼入材の場合にも, 破面単位の大きさはシャ ルピー試験温度によつて変化しないなど，フェライト+ パーライト組織の場合と同様な性質を示している.この ような点からみて破面単位は一般に組織で定まる試料固 有の量であることが明らかになつた.

\section{4. 検討}

\section{1 通移温度と破面単位}

前報まで組織と破面との直接対応法によつて調査を行 なつてきたが4) 6), 靱性と破面単位の間には密接な関係 があり, 本報の結果も含めて, 破面遷移温度 $v T r S$ と $\log l_{\mathrm{c}}^{-1 / 2}$ とは直線関係で整理しうることが示された 5 ). これらの関係は遷移温度に関する РетсH の式2)を利用 したもので, この式での結晶粒径 $l_{\alpha}$ を単に破面単位 $l_{\mathrm{c}}$ で置換したものにすぎない. しかしながら， $l_{\alpha}$ と $l_{\mathrm{c}}$ は
本来異なつたものであり，この差異を検討する必要があ る.

従来, 強度や鞂性についての結晶粒度依存性について は多くの研究が行なわれており, 降伏応力や破壊応力と $l_{\alpha}{ }^{-1 / 2}$ とは直接関係をもつことが知られている. これら の関係については，転位モデルによる説明むいくつかあ り1) 9), 結晶粒度依存性は过り線長さが長いほど転位の 集積による応力集中度が大になることから説明されてい る1，遷移温度に関しては一致した説明はないが，いず れもこれらの転位集積による応力集中を脆性亀裂の発生 によつて緩和するか，もしくは塑性変形によつて䌅和す るかの兼ね合いで論じられ，温度の上昇は，主として塑 性変形応力の低下に影響する形で遷移温度が導かれてい る1) 3).

本報の整理に用いられた破面単位 $l_{\mathrm{c}}$ は䢃開面 $\{100\}$ に関してとらえたものであり，过り面は $\{110\} ，\{112\}$

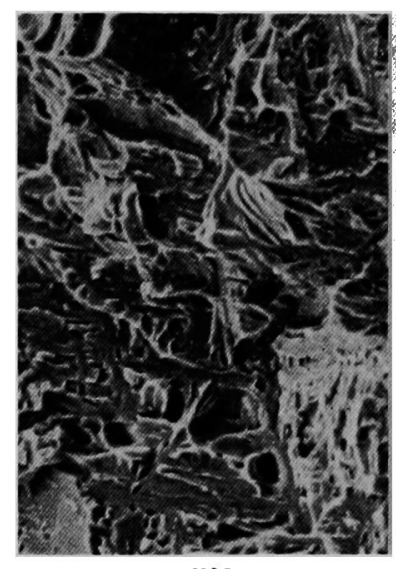

$-60^{\circ} \mathrm{C}$

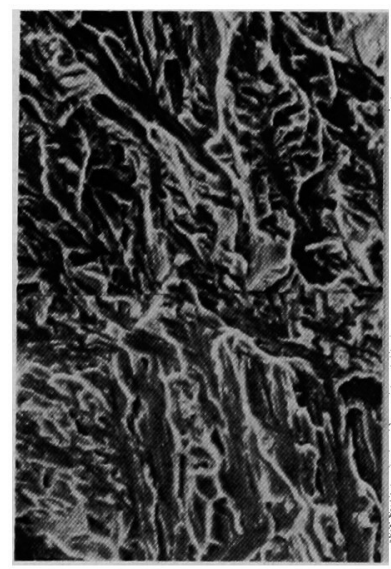

$-120^{\circ} \mathrm{C}$

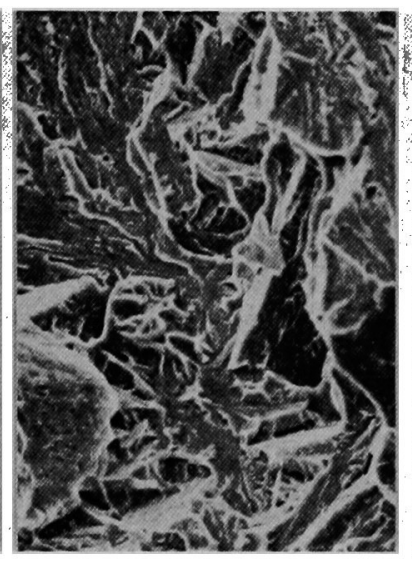

$-40^{\circ} \mathrm{C}$

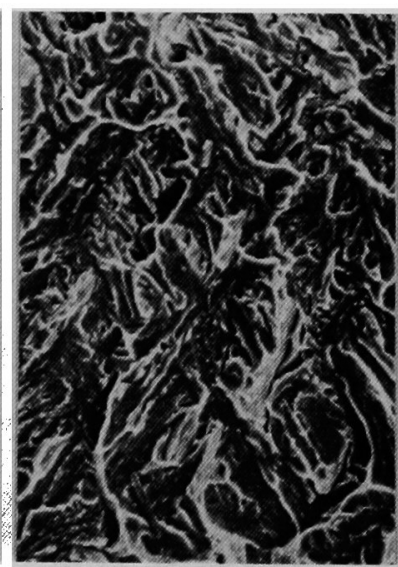

$-100^{\circ} \mathrm{C}$

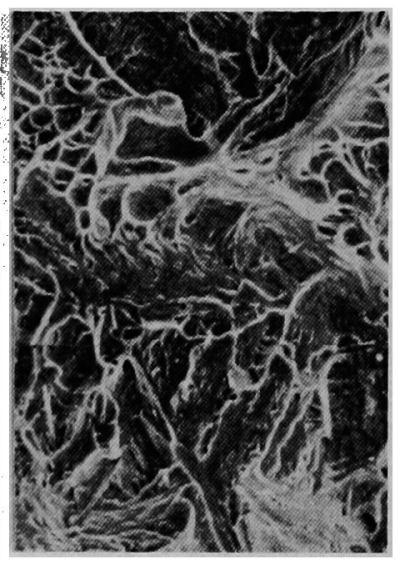

$0^{\circ} \mathrm{C}$

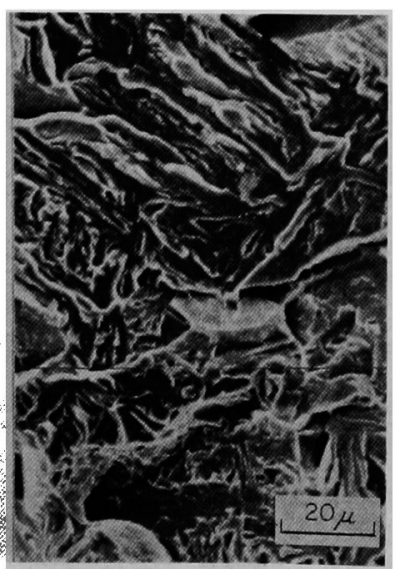

$-80^{\circ} \mathrm{C}$

$\times 800(3 / 5)$

Photo. 5. Variation of fracture appearance with temperature for duplex martensitic-bainitic structure. (steel 7). 

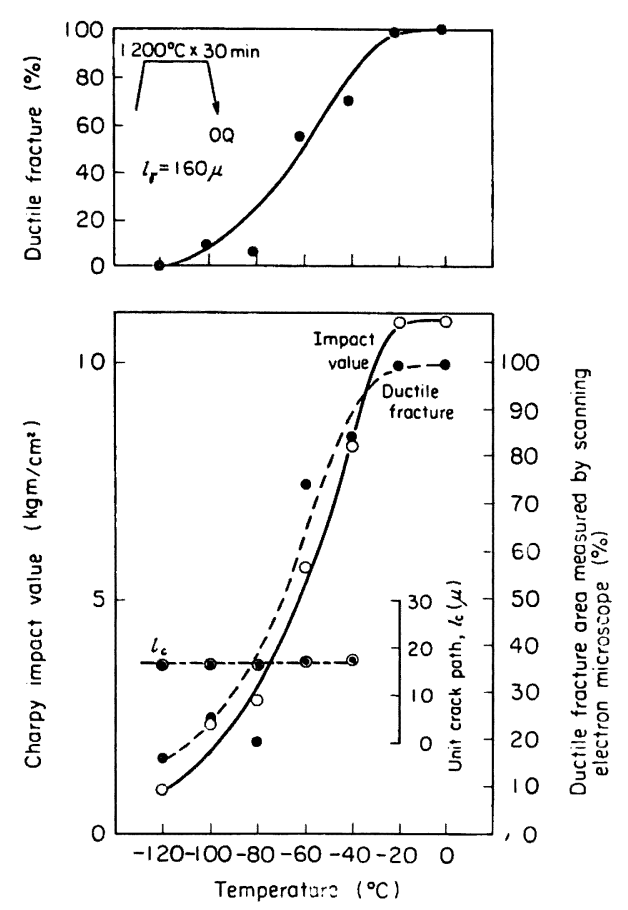

Fig. 4. Charpy impact transition curve, unit crack path and ductile fracture area $(\%)$ measured by scanning electron microscope for duplex martensite-bainite structure. (steel 7)

などである点が異なつている8)99. 本実験結果では $l_{\mathrm{c}} \approx$ $2 l_{\alpha}$ であり $\log l_{\mathrm{c}}^{-1 / 2}$ の整理では同様な形になる. しか しながら，マルテンサイトやベイナイト組織を有する焼 入材などの場合には $l_{\alpha}$ に相当するものは明確ではなく4), またフェライト粒の場合でも必ずしも $l_{\mathrm{c}} \propto l_{\alpha}$ の形にな るとは限らない，たとえば，隣接粒の破面が破面に垂直 な〈100〉軸廻りの回転系列になつている場合には，これ らの隣接粒は同一破面単位に属するが4)，このような方 位関係は艺り線の長さとは別の関係になつている.脆性 破壊応力を Griffith 刍裂の不安定破壊条件で論ずれば, このような転位集積モデルでは艺り線長さが先在亀裂に 対応する ${ }^{3)}$. JoHNSON ${ }^{10)}$ は，遷移領域では結晶粒程度の 安定な皇裂が存在することから, 先在龟裂の長さを粒径 $d$ とおき, 塑性変形応力とのかね合いを論じている．こ のような観点からみれば先在亀裂長さを破面単位と考え れば, 脆性破壊力に関する限り, 従来の $l_{\alpha}$ を $l_{\mathrm{c}}$ で置き 換えることはそれほど意味の違いはない，遭移温度の論 議には, 塑性変形応力の温度依存性や粒度依存性が重要 になる.

しかしながら，塑性変形による緩和過程を単に，引張
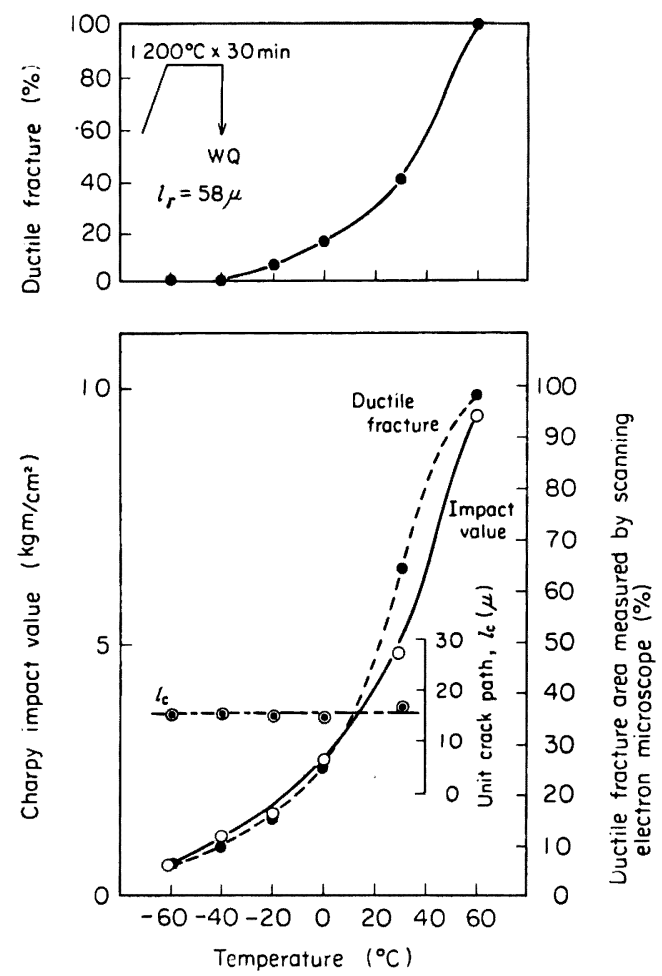

Fig. 5. Charpy impact transition curve, unit crack path and ductile fracture area measured by scanning electron microscope for martensite structure. (steel 8)

試験における降伏応力の類で論議できるかどうかも問題 であり，遷移温度の種類やそれを得る試験方法などによ つて取扱いは異なつてくるものと考えられる．これらの 解析には, シャルピー泪撃破面遷移温度はかなり複雑で あり，本報では単に実伢結果として $v \operatorname{Tr} S$ と $\log l_{\mathrm{c}}-1 / 2$ の関係にとどめておく.

\section{$\mathbf{4 . 2}$ 脆性破面の温度变化}

衝撃破断試験温度が上昇すれば，マク口的観察では破 面の周囲に延性破壞領域が増加するが，さらに，ミクロ 観察では残存脆性破面自体も变化している.

すなわち，温度の上昇とともに破面単位の周囲に延性 破面带が生じ，車裂の不連続性がより明確になる．この 延性破面帶は網目状に観察され, さらに温度の上昇とと もに一部の破面単位全体が延性破壊を生ずるようにな る.これらの温度の影響は, 走査電顕による本報程度の 粗い観察では破面単位内部の変化はほとんどみられず, 単に延性破面部の增加で示される. また延性破面率の温 度変化と吸収エネルギーの温度変化はよい対応を示して いるので，脆性破面の表面エネルギーを無視して計算す 


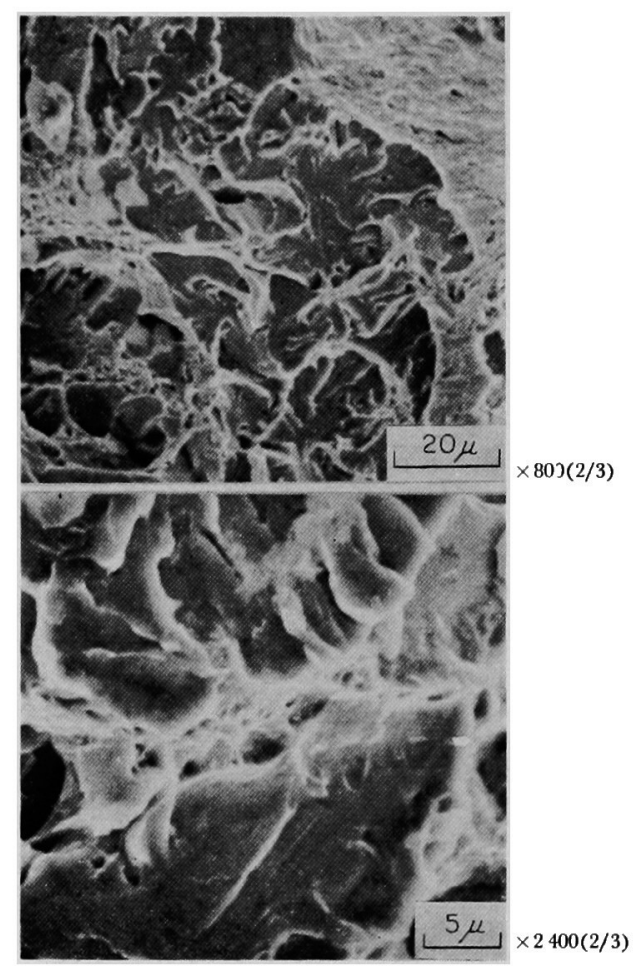

Photo. 6. Fracture appearance of $9 \% \mathrm{Ni}$ steel at $-196^{\circ} \mathrm{C}$.

れば，延性破面の表面エネルギー自体の温度変化も実験 範囲内でそれほど大きくはない，このような，マク口的 な脆性破面中の延性破面の存在形態は, フラクトグラフ ィーなどの破断温度の推定に有用なばかりでなく, 材料 自体の靶性の論議に有用と思われる.9\% Ni 鋼などは, 䩖性に富えだ材料として知られており，-196 ${ }^{\circ} \mathrm{C}$ におい ても完全な脆性破面を得ることは困難である. マク口的 には脆性破面の様相を示していても，之ク口的に観察す れば, Photo. 6 に示すごとく延性破面が網目状に存在し ているが，このような延性破面帯を残留オーステナイト 存在域とする解釈もある11). しかしながら, 本実験結果 を勘案すれば, 必ずしも残留オーステナイトの存在は必 要ではなく, 破面単位程度の粗さでいえば単なるマトリ ックスの靫性の増加と同様な形態を示している.

以上, 前報4 6) 含めて遷移温度と破面単位の関連を 調査し，これを通じて靶性におよぼす変態組織の影響を 論じた.しかしながら, 本実験程度の粗さでは, $\gamma / \alpha$ 変 態を通じてフェライト組織の分割の靶性入の効果が検討 されたにすぎない. Ni 添加によるマトリックス靶性強 化の効果や, 強度因子, たとえば, マルテンサイトラス の大きさ，微細炭化物の分布などを論ずるためには，さ
らに微細な観察が必要であるが，これらの俔々の効果を 独立に調査与ることは通常困難であり，フェライト分割 効果の上に立つて諭ずることは，問題の明確化に有用と 考えられる.

\section{5. 結}

言

前報4 (6)まで鉄銅材料の各種变態組織と低温脆性破面 との直接対応から脆性破面を構成する微細皇裂（破面単 位）は，組織から説明しうることを示した．高張力鋼の 連続冷却变態組織の場合5には， $l_{\mathrm{c}}$ と破面遥移温度 $v T r S$ はよく対応するが，遷移温度と $l_{\mathrm{c}}$ との対応を論ずる場 合には，遷移領域での破面の様相を調査する必要があ る.

この意味から, 本報では, 主として低炭素鋼のフェラ イトトパーライト組織について調査を行なつた. その結 果, 破面単位は破断温度によつて変化せず, 組織固有の 量であることが明らかとなつた. フェライト+パーライ 卜組織についてオーステナイト化温度および泠却速度を 変えて熱処理された試料について, を求めた. $v T r S$ と $\log l_{\mathrm{c}^{-1 / 2}}$ とは直線関係にあり, 空 冷，炉冷の差は $l_{\mathrm{c}}$ に差を与えるが対応関係は变わらな い.オーステナイト粒径 $\left(l_{r}\right)$ と $l_{\mathrm{c}}$ の間には直線関係は なく, 一方, フェライト粒径 $\left(l_{\alpha}\right)$ と $l_{\mathrm{c}}$ の間には直線関 係があり， $l_{\mathrm{c}} \sim 2 l_{\alpha}$ であつた. この意味から，本報のご

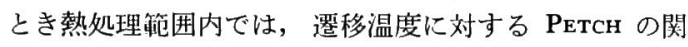
係の域を出なかつたが，一般には $l_{\mathrm{c}}$ と $l_{\alpha}$ は対応しなく てもよく, またこの $l_{\mathrm{c}}$ と $v \operatorname{Tr} S$ の関係は, 焼入組織な どにも延長し得る点が重要である5). 破断試験温度の影 響は, 温度の上昇とともに, マク口的な延性破面の増加 のほかに脆性破面内部では，破面単位の周囲に延性破面 带が生ずる.ついで一部分の破面単位全体が延性破断面 に変化し, 延性破壊へ至つている. このような傾向は焼 入組織の場合も同様である. 吸収エネルギーの变化はミ ク口的な延性破面率の変化と一致し, この点から破断試 験温度の上昇は, 脆性もしくは延性破面自体の变化より も, 単なる延性破面の増加をもたらすものと考えられる. 破面遷移温度 (vTrS) と破面単位の関係については, 一般に従来の結晶粒度依存性と同様に論ずることはでき ないが，これらの点に関しては，さらに遷移現象につい て実験的なデータを重极, 強度などとの関連において論 ずる必要がある。

おわりに, 本研究の発表を許可された中央技術研究所 所長 住友元夫博士, ならびに終始有益なご助言をいた だいた, 邦武立郎博士に深甚なる感謝の意を表する.

また，実験にご協力いただいた，小谷誠一氏，上野谷 
繁雄氏に感謝します。

\section{文 献}

1) A. N. Stron: Adv. Phys., 6 (1957), p. 48

2 ) N. J. Petch: Phil. Mag., 3 (1958), p. 1089

3 ) A. H. Cotrrell: Trans. AIME, 212 (1958), p. 192

4 ) 寺䗁, 大谷：鉄と鋼，58 (1972), p. 293

5 ）大谷, 寺崎, 邦武: 鉄と鋼, 58 (1972), p. 434
6 ) 大谷，寺崎：鉄と鋼，58（1972）揭載予定

7 ) C. A. Dubé, H. I. Aaronson, and R. F. Mehl: Rev. Met., 55 (1958), p. 201

8 ) F. Terasaki: Métaux et Corrosion Industries, (1967) 498, p. 1

9) F. Terasaki: Acta Met., 15 (1967), p. 1057

10) A. A. Johnson: Phil. Mag., 8 (1962), p. 177

11）長谷川，佐野：鉄と鋼，56 (1970), S 170 